\title{
Lyme disease in the differential diagnosis of rheumatoid arthritis
}

\section{Romatoid artritin ayırıcı tanısında Lyme hastalığı}

Ahmet Karadağ ${ }^{1}$, Müjde Karadağ ${ }^{2}$, Sevil Ceyhan Doğan ${ }^{1}$, Emrullah Hayta ${ }^{1}$

Department of Physical Medicine and Rehabilitation, Cumhuriyet University, Sivas
Department of Otolaryngology, Sivas Numune Hospital, Sivas
Corresponding author: Department of Physical Medicine and Rehabilitation, Cumhuriyet University, TR-58140, Sivas,
TURKEY
E-mail: dr_ahmetkaradag@hotmail.com
Received/Accepted: June 15,2015/January 04,2016
Conflict of interest: There is not a conflict of interest.

\section{SUMMARY}

Clinically, there are some differences between rheumatoid arthritis (RA) and Lyme disease. Although Lyme arthritis exhibits marked differences from RA, it can cause erosion at joint due to chronic proliferative synovitis as similar to RA. In the literature, a case was reported where both entities were seen together. In this manuscript, we aimed to present a case with symmetric arthritis at small hand joints and arthralgia at wrist that mimicked RA but diagnosed as Lyme disease by history, clinical presentation and laboratory findings, and successfully treated.

Keywords: Lyme disease, rheumatoid arthritis, Borrelia burgdorferi

ÖZET

Romatoid artrit (RA) ile Lyme hastalığ klinik olarak farklllıklar göstermektedir. Lyme artriti RA'dan belirgin farklilıklar göstermesine ragmen, benzer bir şekilde kronik proliferatif sinovitise bağlı olarak eklem yerlerinde erozyona neden olabilmektedir. Literatürde her iki hastalığın birlikte görüldüğü olguda bildirilmiştir. Biz bu makalede el küçük eklemlerinde simetrik artriti ve el bileklerinde artraljisi olup RA'y1 taklit eden ancak öykü, klinik ve laboratuvar olarak Lyme Hastalığ $\tan _{1 s}$ koyduğumuz ve tedavisi tamamlanan bir vakayı sunmayı amaçladık.

Anahtar sözcükler: Lyme hastalı̆̆1, romatoid artrit, Borrelia burgdorferi

\section{INTRODUCTION}

Lyme disease is a rarely encountered entity in our country, which is caused by a spirochete, namely Borrelia burgdorferi, and involves many systems including skin, joins, heart and central nervous system. It may cause chronic inflammatory response by its late complications ${ }^{1}$. In Lyme disease, B. burgdorferi begins to spread from bite site to periphery after incubation period of 3-32 days and this causes typical skin findings.

Microorganism can spread to heart, central nervous system, joints, liver and spleen through blood stream. Specific IgM is elevated in the blood between weeks 3 and
6. It may take months or years for elevation of specific IgG in sera. Infected ticks transmit disease to the host while feeding by human blood. As tick bite is painless, there is no history of tick bite in majority of the patients with Lyme disease $^{2,3}$.

Rheumatoid arthritis is an auto-immune, chronic inflammatory disease that involves many synovial joints. Its etiology and pathogenesis aren't fully understood. The disease causes cartilage and bone damage by affecting synovial joints symmetrically ${ }^{4}$. Mild and temporary joint involvement may be seen in some patients, while disability and major organ damage can developed despite intensive therapy in 
some other. Intermittent mono or oligoarthritis, frequently at knee joint, can develop in the half of treatment-naive cases with Lyme disease ${ }^{1}$. Thus, RA and Lyme disease can be confused at clinical grounds.

In this report, we aimed to review literature by presenting a case with symmetric arthritis at small hand joints and arthralgia at wrist that mimicked RA but diagnosed as Lyme disease by history, clinical presentation and laboratory findings and successfully treated.

\section{CASE REPORT}

A 30-years old woman presented to our outpatient clinic with pain at fingers and wrists over 5 months, fatigue and tiredness. In detailed history taking, it was found that the patient felt tired over a long period and that she had morning stiffness lasting more than 30 minutes and arthralgia which relieves with non-steroidal antiinflammatory drugs. There was history of local erythema at inguinal region that lasted a few weeks after insect bite when she was abroad (Germany). On the physical examination there was bilateral swelling, tenderness at palpation and minimal calor in 2nd and 3rd proximal interphalangeal joints and tenderness at palpation in the wrists. There was no other abnormal finding in the physical examination. Laboratory evaluations were as follows: WBC, 9600/uL; Hgb, 12.1 g/dL; PLT, 376,000/uL; ESR, $15 \mathrm{~mm} / \mathrm{h}$; RF, 7 IU/ml (0-14); CRP, $2.45 \mathrm{mg} / \mathrm{dL}$ (01); Anti CCP (-); ANA (-); hepatitis panel $(-)$; liver and kidney function tests within normal range; and normal bilateral anterioposterior hand-wrist radiographs.

Given the normal laboratory findings other than CRP, the patient living abroad and history of skin lesion following insect bite, Lyme disease was considered and IgM and IgG antibodies for B. burgdorferi were ordered to a specialized laboratory. These antibodies were found as positive; thus, serological results were confirmed by Western blot technique. The patient was diagnosed as Lyme disease; thus, indomethacin (PO 3x50 $\mathrm{mg} /$ day) and doxycycline (PO 2x100 mg/day, over 30 days) were prescribed to the patient. The symptoms were resolved by this therapy.

\section{DISCUSSION}

Lyme disease is rather rare although $\mathrm{B}$. burgdorferi seroprevalence has been reported as $36 \%$ at rural regions in our countryb $^{5}$. Clinical symptoms vary based on phase of disease. Lyme disease can be defined in 3 phases. In the first phase, there are skin lesions and erythema chronicum migrans (ECM). In the second phase, there are fever, adenopathy, flu, neurological abnormalities, cardiac abnormalities, migrating joint pain and oligoarticular arthritis. In the third phase, findings such as chronic arthritis, myocarditis and subacute encephalopathy are observed after many years ${ }^{6}$. In Lyme disease, articular findings appear as arthralgia, acute arthritis or chronic arthritis. One or more joints can be involved intermittently in acute Lyme arthritis.

In Lyme disease, diagnosis is usually made by laboratory evaluations. It is possible to obtain cure in Lyme disease and it can cause severe complications unless treated. Thus, it is warranted to rule Lyme disease when there is clinical suspicious.

This case is valuable as it indicated that soma rare disease may become increasingly prevalent due to tourism accommodation and that Lyme disease is one of the disorders which should be into account in the differential diagnosis of rheumatoid arthritis as well as it emphasize importance of history taking in physical rehabilitation and rheumatology practice due to several disease with potential to cause musculoskeletal symptoms.

\section{REFERENCES}

1. Steera AC. Borrelia burgdorferi, pp: 2798-810. In: Mandell GL, Bennett JE, Dolin R (eds), Principles and Practice of Infectious Diseases, 6th ed. Churchill Livingstone, New York 2005.

2. Steere AC, Schoen RT, Taylor E. The clinical evolution of Lyme arthritis Ann Intern Med 1987; 107: 725-31.

3. Jaulhac B, Chary-Valckenaere I, Sibilia J. Detection of Borrelia 
burgdorferi by DNA amplification in synovial tissue samples from patients with Lyme arthritis. Arthritis Rheum 1996; 39: 736-45.

4. Takatsu M, Higaki M, Kinoshita H, Mizushima Y, Koizuka I. Ear involvement in patients with rheumatoid arthritis. Otol Neurotol 2005; 266: 755-1.

5. Onen F, Tuncer D, Akar S. Seroprevalence of Borrelia burgdorferi in patients with Behcet's disease. Rheumatol Int 2003; 23: 289-93.

6. Meredith JT. Infection from animals. Tintinalli JE, Kelen GD, Stapczynki JS. Emergency Medicine A Comprehensive Study Guide, McGraw\&Hill, 5th ed. 2000; 991-1001. 